This is an author produced version of a paper published in Biomacromolecules.

This paper has been peer-reviewed and is proof-corrected, but does not include the journal pagination.

Citation for the published paper:

Faraz Muneer, Mariette Andersson, Kristine Koch, Carolin Menzel, Mikael

S. Hedenqvist, Mikael Gällstedt, Tomás S. Plivelic and Ramune Kuktaite.

(2015) Nanostructural Morphology of Plasticized Wheat Gluten and

Modified Potato Starch Composites: Relationship to Mechanical and Barrier

Properties. Biomacromolecules. Volume: 16, Number: 3, pp 695-705.

http://dx.doi.org/10.1021/bm5017496.

Access to the published version may require journal subscription.

Published with permission from: ACS Publications, as mandated by funder MISTRA.

Standard set statement from the publisher:

"This document is the Accepted Manuscript version of a Published Work that appeared in final form in Biomacromolecules, copyright $(C)$ American Chemical Society after peer review and technical editing by the publisher. To access the final edited and published work see http://dx.doi.org/10.1021/bm5017496 . “

Epsilon Open Archive http://epsilon.slu.se 


\section{Nano-structural morphology of plasticized wheat gluten and modified potato starch composites: relationship to mechanical and barrier properties}

Faraz Muneer, ${ }^{*}$ Mariette Andersson, ${ }^{\dagger}$ Kristine Koch, ${ }^{\dagger}$ Carolin Menzel, ${ }^{\dagger}$ Mikael S. Hedenqvist,${ }^{\S}$ Mikael Gällstedt, ${ }^{¥}$ Tomás S. Plivelic, ${ }^{\mathfrak{E}}$ Ramune Kuktaite ${ }^{* \mathfrak{*}}$

${ }^{\ddagger}$ Department of Plant Breeding, Swedish University of Agricultural Sciences, Box 101, SE23053 Alnarp, Sweden,

${ }^{\dagger}$ Department of Food Science, Swedish University of Agricultural Sciences, Box 7051, SE-750

07 Uppsala, Sweden

${ }^{\S}$ KTH Royal Institute of Technology, School of Chemical Science and Engineering, Fibre and Polymer Technology, SE-100 44 Stockholm, Sweden

${ }^{¥}$ Innventia AB, Box 5604, SE-114 86 Stockholm, Sweden

${ }^{\mathfrak{E}}$ MAX-IV Laboratory, Lund University, Box 118, SE-221 00 Lund, Sweden

*Corresponding authors e-mail: faraz.muneer@ slu.se and ramune.kuktaite@ @lu.se 


\begin{abstract}
In the present study, we were able to produce composites of wheat gluten (WG) protein and a novel genetically modified potato starch (MPS) with attractive mechanical and gas barrier properties using extrusion. Characterization of the MPS revealed an altered chain length distribution of the amylopectin fraction and slightly increased amylose content compared to wild type potato starch. WG and MPS of different ratios plasticized with either glycerol or glycerol and water were extruded at 110 and $130^{\circ} \mathrm{C}$. The nano morphology of the composites showed the MPS having semi-crystalline structure of a characteristic lamellar arrangement with an approximately $100 \AA$ period observed by SAXS and a B-type crystal structure observed by WAXS. WG has a structure resembling the hexagonal macromolecular arrangement as reported previously in WG films. A larger amount of $\beta$-sheets was observed in the samples 70/30 and $30 / 70$ WG-MPS processed at $130^{\circ} \mathrm{C}$ with $45 \%$ glycerol. Highly polymerized WG protein was found in the samples processed at $130^{\circ} \mathrm{C}$ vs. $110^{\circ} \mathrm{C}$. Also, greater amounts of WG protein in the blend resulted in greater extensibility $\left(110^{\circ} \mathrm{C}\right)$, and a decrease in both E-modulus and maximum stress at 110 and $130^{\circ} \mathrm{C}$, respectively. Under ambient conditions the WG-MPS composite (70/30) with $45 \%$ glycerol showed excellent gas barrier properties to be further explored in multilayer film packaging applications.
\end{abstract}

Key words: Wheat gluten, modified potato starch, composites, nano-structure, tensile properties, oxygen permeability 


\section{Introduction}

During the last two decades, abundantly available and relatively inexpensive plant polymers such as wheat gluten (WG) protein and starch, have become important alternatives in replacing petroleum based synthetic polymers for the production of bio-plastics. ${ }^{1}$ Wheat gluten, a byproduct of the wheat starch industry with attractive viscoelastic properties, has been successfully used for making gluten-hemp materials, ${ }^{2-4}$ foams, ${ }^{5}$ and nanoclay-composites. ${ }^{6}$ Starches from various plants are widely used today as a raw material in the production of bioplastics, mainly for thermo-plasticized packaging materials. ${ }^{7}$ Several studies exist regarding the improved mechanical properties of thermoplastic material derived from chemically and genetically modified potato starch. ${ }^{8,9}$ Both WG protein, ${ }^{2,10}$ and potato starch materials ${ }^{8,11}$ show attractive mechanical and gas barrier properties. However, material properties are often negatively affected by processing parameters such as plasticization, and hence further development is needed to improve these polymers use as packaging materials. A combination of $\mathrm{WG}$ and potato starch into a composite might be a promising and cost competitive alternative, which has not been previously explored.

Wheat gluten protein consists of polypeptides joined with disulphide and hydrogen bonds forming a three-dimensional polymer network, ${ }^{12}$ and this network governs the functional properties of WG materials. In WG based materials with glycerol (and urea with or without nano-clays) a hierarchical hexagonal structure of proteins was found to be inter-related with improved mechanical and barrier performance of the materials, ${ }^{6,13}$ since protein structure and functional properties are closely related. This gives a background for further exploring WG proteins in various formulations, such as with potato starch in order to explain the impact of these hexagonal structures on the functionality of those materials. 
Potato starch is composed of amylose and amylopectin molecules having specific structures, mainly long linear chains for amylose while amylopectin is highly branched with shorter chains than amylose. Various ratios of amylose and amylopectin are known to be responsible for different physiochemical properties and end-use quality of starch based materials. ${ }^{14}$ In the present study, potato starch, modified to yield increased lengths of the glucan chains in amylopectin fraction and higher amylose content, was produced and combined with WG for making biocomposites using extrusion. It has been reported that long linear glucans, like amylose molecules, tend to form more entanglements compared to highly branched amylopectin molecules. ${ }^{15}$ Therefore, the long chained amylopectin starch used in the present study should act as a linear chain and have an influence on the chain entanglements development during extrusion. For bio-based materials it is of interest, from a techno-functional point of view, to explore a potato starch with amylopectin of longer chains length and decreased degree of branching as a good potential raw material for improved packaging materials.

From recent studies on protein-starch materials, egg albumen protein-corn/potato starch composites have shown higher strength (at low deformation) comparable to commodity plastics. ${ }^{16}$ The functional properties of these albumen/starch based materials were greatly influenced by the processing conditions used. ${ }^{16}$ In addition, a study on the solution cast films, produced from separated wheat gluten and native wheat starch, investigated the water vapor sorption mechanisms and dynamics of both polymers. ${ }^{17}$ To conclude, the need to control functional properties such as mechanical, gas/water barrier, water sorption etc. of protein and starch materials is currently under focus.

According to our knowledge, none of the previous studies have investigated the use of modified potato starch (MPS) in combination with WG proteins in order to produce a composite using 
extrusion processing. We aimed at studying the structural organization of WG proteins and MPS, and the effects of WG protein polymerization, composition of the blend and extrusion temperature on the mechanical and gas barrier properties of the composites.

\section{Experimental}

\section{Materials}

Wheat gluten was supplied by Lantmännen Reppe AB, Lidköping, Sweden. The gluten protein content was $77.7 \%$, starch $5.8 \%$, moisture $6.9 \%$ and fat content $1.2 \%$, according to the supplier. Starch from genetically modified potato Line 2012, further referred to as modified potato starch (MPS), was developed at the Swedish University of Agricultural Sciences, Alnarp, Sweden as described in methods section. The MPS and its parental variety Dinamo were processed by Lyckeby Starch AB, Sweden. Glycerol (purity 99.5 wt\%, 0.5 wt\% water) was supplied by Karlshamns Tefac AB, Karlshamn, Sweden.

\section{Methods}

\section{Potato starch modification and characterization}

Starch with an altered chain length distribution was developed by inhibition of the starch branching enzyme genes $S B E 1$ and $S B E 2$ in potato using RNA interference (RNAi). An RNAi fragment containing a small region of each $S B E$ gene ${ }^{18}$ was synthetically produced in tandem and cloned as an inverted repeat in the binary vector pGWIWgbss using the Gateway® system (Invitrogen, Carlsbad, CA, USA). The binary vector pGWIWgbss is a modified version of the

pK7GWIWG2(II) vector, ${ }^{19}$ where the $35 \mathrm{~S}$ promoter has been exchanged by a granular bound starch synthase promoter (GBSS) of Solanum tuberosum origin pK7GWIWG2(II). ${ }^{19}$ Potato 
cultivar Dinamo was transformed using Agrobacterium tumefaciens strain AGLO harboring the RNAi construct. Transformation, regeneration and selection of lines were performed as described previously ${ }^{20}$ with the modification that $50 \mathrm{mg} / \mathrm{l} \mathrm{kanamycin}$ was used as selection agent. Potato plants were field grown between May and October 2012, and the starch was processed in an industrial pilot plant (Lyckeby Starch AB, Kristianstad, Sweden). Characterization of the modified and native type starches included amylose content according to Chrastil, ${ }^{21}$ and chainlength distribution using gel permeation chromatography after de-branching according to Bertoft et $\mathrm{al}^{22}$. Pasting characteristics of the two starches were determined using a rapid viscoanalyzer (Newport Scientific Method 1 as defined by the manufacturer; Newport Scientific, Warriewood, NSW, Australia), and granule shape and size were investigated using a scanning electron microscopy (Hitachi TM-1000-micro, Hitachi, Tokyo, Japan).

\section{Sample preparation and extrusion}

Wheat gluten and MPS blends were hand mixed with ratios of 70/30, 50/50 and 30/70 (wt. \%), and glycerol content of either 30 or $45 \%$ (wt. \% of the total wt. of the sample) were produced. For some samples the addition of $20 \%$ water was tested. The sample composition and abbreviations are presented in Table 1 (Supplementary information). Efforts were made to obtain protein based control samples from as received WG protein (45\% glycerol). The WG-glycerol extrudates resulted in disrupted and non-homogeneous samples and therefore were only used for studying WG protein molecular size distribution by size exclusion high performance liquid chromatography (SE-HPLC). The WG-MPS composites were extruded at $110^{\circ} \mathrm{C}$ and $130^{\circ} \mathrm{C}$ using a Haake Minilab twin screw extruder (feeding rate was less than a $\mathrm{kg} / \mathrm{h}$ ) (Thermo Scientific Corporation, Germany) at $30 \mathrm{rpm}$ in the form of strips 3.9-4.1 mm wide and 1.1-1.6 mm thick. A single temperature zone was used and the temperature was kept constant across the 
extruder barrel till the die exit. At least ten strips each with a minimum length of $70 \mathrm{~mm}$ were used for each specimen.

\section{Protein solubility analysis by SE-HPLC}

The protein amount and size distribution analysis by SE-HPLC has been performed according to a three step extraction procedure, e.g. extraction with a buffer followed by a two-step extraction by both buffer and sonication, according a method adopted from Newson et al. ${ }^{23}$. To measure both the soluble amount of protein and evaluate the size distribution of protein each of the extractions were evaluated by SE-HPLC, and protein solubility/extractability was calculated on the basis of total extractable protein.

The samples were prepared by cutting the material into pieces of approximately $0.2 \mathrm{~mm}$ in size using a scalpel. For protein extraction $16.5 \mathrm{mg}( \pm 0.05 \mathrm{mg})$ of protein-starch composite was mixed with $1.4 \mathrm{ml}$ buffer solution (0.5\% SDS, 0.05M NaH $\left.2 \mathrm{PO}_{4}, \mathrm{pH} 6.9\right)$ in a $1.5 \mathrm{ml}$ Eppendorf tube. The samples with buffer solution were vortexed for $10 \mathrm{sec}$ in Whirli Vib 2 (Labassco, Sweden) and shaken for 5 min in IKA-VIBRAX VXR (IKA, Germany) at $2000 \mathrm{rpm}$, and later centrifuged (Legend Micro 17, Sorvall, Germany) for $30 \mathrm{~min}$ at $12500 \mathrm{rpm}$. This supernatant was designated as the first extraction (1Ex). For the second extraction (2Ex), $1.4 \mathrm{ml}$ buffer solution was added to the pellet from 1Ex, sonicated for $30 \mathrm{sec}$ at amplitude of 5 microns using a Sanyo Soniprep 150 Ultrasonic Disintegrator (Tamro, United Kingdom) and centrifuged for 30 min as 1Ex. For the third extraction (3Ex), $1.4 \mathrm{ml}$ buffer solution was added to the pellet from the $2 \mathrm{Ex}$ and sonicated for $30+60+60 \mathrm{sec}$ followed by centrifugation. The samples were left to cool at room temperature during each sonication interval in the 3Ex step to avoid overheating. After sonication, the amount and size distribution of proteins in centrifuged samples from 1Ex, 
2Ex and 3Ex were analyzed with a Waters 2690 Separation Module and Waters 996 Photodiode Array Detector (Waters, USA) according to Newson et al. ${ }^{23}$. For analysis, $20 \mu 1$ of each sample was injected onto an SE-HPLC column (Biosep-SEC-S 4000, Phenomenex, USA), at an isocratic flow of $0.2 \mathrm{ml} / \mathrm{min}$ (50\% acetonitrile, $0.1 \%$ TFA; $\left.50 \% \mathrm{H}_{2} \mathrm{O}, 0.1 \% \mathrm{TFA}\right)$. Empower Pro software (Waters, USA) was used for analysis of data (at $210 \mathrm{~nm}$ ) and chromatograms representing the amount and size distribution of proteins were integrated and divided into two groups of proteins, polymeric (retention time 7-14 $\mathrm{min}$ ) and monomeric (14-28 $\mathrm{min})$. The obtained data were corrected for the initial protein content for each individual sample.

\section{Tensile testing}

The strips of the extruded samples were cut into a minimum length of $70 \mathrm{~mm}$ for tensile testing. The samples were conditioned for $48 \mathrm{~h}$ at $50 \%( \pm 2)$ relative humidity $(\mathrm{RH})$ and $23^{\circ} \mathrm{C}$ before testing and thereafter the test was performed in the same conditions. Width and thickness of the samples were measured using Mitutoyo IDC 112B at five different points. A $100 \mathrm{~N}$ load cell, clamp separation distance of $40 \mathrm{~mm}$ and crosshead speed of $10 \mathrm{~mm} / \mathrm{min}$ was used for all samples on an Instron 5566 universal test machine using Bluehill software (Instron AB, Danderyd, Sweden).

\section{Fourier transform infrared spectroscopy}

FT-IR spectroscopy analysis was carried out on all the extruded samples and WG powder using a Spectrum 2000 FTIR spectrometer (Perkin-Elmer inc., USA) equipped with single reflection ATR (Golden Gate, Speac Ltd.). Prior to analysis the samples were dried for at least $72 \mathrm{~h}$ in a desiccator using silica gel. 


\section{Scanning electron microscopy}

The scanning electron microscope (SEM) (LEO 435VP, Cambridge, UK), acceleration voltage of $10 \mathrm{kV}$ and secondary electron detection was used for the evaluation of the WG-MPS/ MPS materials. The WG-MPS-45gly (70/30), WG-MPS-30gly-20W (70/30) and MPS-45gly samples were analyzed for the cross-sectional microstructure. The cross-section of the sample was prepared by cutting using a scalpel. Samples were coated with Au/Pd 3:2 coating (JFC-1100, JEOL, Tokyo, Japan).

\section{Small angle $X$-ray scattering}

All the extruded samples were analyzed by small angle X-ray scattering (SAXS). The SAXS experiments were carried out at the MAX-IV Synchrotron Laboratory, Lund, Sweden, using the beamline I911-4 with a wavelength of $\lambda=0.91 \AA .^{24}$ The scattering vector range $q(q=4 \pi / \lambda$ $\sin (\theta)$, where $2 \theta$ is the scattering angle) was $0.0082-0.47 \AA^{-1}$. A bi-dimensional hybrid pixel Xray detector (Pilatus 1M, Dectris) was used to obtain two-dimensional images with sample to detector distance of $1901.71 \mathrm{~mm}$ and an exposure time of either 2 or $5 \mathrm{~min}$. The SAXS data were

analyzed using the software bli9114. ${ }^{24}$ The obtained data were normalized with respect to integrated intensity incident on the sample during the exposure time and corrected for sample absorption and background.

To get additional details on the structure of WG-MPS composites, SAXS measurements at different temperatures were performed for the WG-MPS-45gly $70 / 30\left(110^{\circ} \mathrm{C}\right)$. The temperatures used were $25,35,45,55,60,75,80$ and $90^{\circ} \mathrm{C}$ with an exposure time of $60 \mathrm{~s}$. The temperature at each step was kept constant for 5 min before a SAXS image was taken. 


\section{Wide angle X-ray Scattering}

Wide angle X-ray scattering analysis (WAXS) was carried out at the MAX-IV Synchrotron Laboratory, Lund, Sweden, using beamline $1911-2^{25}$ with a wavelength of $\lambda=1.04 \AA$ and a sample to detector distance of $149.8 \mathrm{~mm}$. An area-CCD detector was used for the measurements. Silicon powder was used as a standard for calibration. The data was analyzed using Fit2D software. $^{26}$

\section{Oxygen permeability}

The samples for oxygen permeability were made by cutting the strips of extruded samples into small pallets $(2-4 \mathrm{~mm})$ using scalpel. The pallets were placed in a metal frame of a $1 \mathrm{~mm}$ thickness and 70x70 mm opening to control the size and thickness of the film. The pallets were then pressed in a hot compression molding machine (Polystat 400s, Servitech, Germany) between two aluminum plates for $10 \mathrm{~min}$ at a constant pressure (200 bars) and temperature $\left(130^{\circ} \mathrm{C}\right)$. The samples were conditioned at $23^{\circ} \mathrm{C}$ and $50 \% \mathrm{RH}$ for $16 \mathrm{~h}$ prior to the test. Oxygen transmission rate analysis was carried using Ox-Tran 2/21 (Mocon Inc., MN, USA), according to ASTM F1927-07. The test was carried out on a measured area of $5 \mathrm{~cm}^{2}$ and gas flow of 10 $\mathrm{ml} / \mathrm{min}$. The oxygen transmission data were normalized to the oxygen pressure and the thickness

of the samples to get the oxygen permeability values. Two replicates for each sample were tested. 


\section{Results and Discussion}

\section{Molecular characterization of potato starch}

The potato variety Dinamo was genetically modified in order to produce a starch with decreased degree of branching and increased length of glucan chains, by targeting two starch branching enzyme genes, SBE1 and SBE2. The MPS showed a significant increase in total amylose content from 18 to $27 \%$ compared to the parental variety (Table 2, Supplementary information). Gel permeation chromatography after starch de-branching showed that the chain-length distribution of MPS was altered compared to the parental variety. Long chain amylose molecules eluted first (between 40 and $50 \mathrm{~mL}$ ) and shorter chains from de-branched amylopectin eluted later in the chromatogram (between 75 and $100 \mathrm{~mL}$ ) (Fig. 1a). The MPS showed a shift in the chromatographic profile seen as an earlier second eluting peak (pointed line) indicating a higher amount of long chains from de-branched amylopectin compared to the parental variety Dinamo (Fig. 1a). The pasting properties of the MPS differed significantly from Dinamo, indicating higher gelatinization temperature, final viscosity and set back, but a lower peak viscosity and breakdown for the MPS (Table 2, Supplementary information). A higher amylose content and longer chain-length of amylopectin are known to affect pasting properties. ${ }^{27}$ The results in this study confirmed the altered molecular structure seen by gel permeation chromatography. Scanning electron microscopy of MPS showed different starch granule morphology compared to Dinamo where the MPS granules were smaller in size, had irregular shapes and a slightly fissured phenotypic appearance (Fig. 1 b, c; indicated by arrows). The uneven granule shape has

previously been shown to be related to the change in chain-length of amylopectin and amylose. ${ }^{28,}$ 29 


\section{Temperature effect on protein polymerization in protein-starch composites}

The WG-MPS composites containing two plasticizers combinations one with $45 \%$ glycerol and other $30 \%$ glycerol with $20 \%$ water were extruded at $110^{\circ} \mathrm{C}$ and $130^{\circ} \mathrm{C}$, and were analyzed for the soluble amount and size distribution of protein by SE-HPLC (Fig. 2). A significant decrease in protein solubility was observed in all the WG-MPS-45gly and WG-MPS-30gly-20W composites compared to the WG-45gly samples produced at the studied temperatures (Fig. 2). Significantly smaller amounts of both polymeric and monomeric proteins were extracted in the WG-MPS-45gly composites extruded at $130^{\circ} \mathrm{C}$ compared to those extruded at $110^{\circ} \mathrm{C}$. For the WG-MPS-45gly samples $30 / 70$ and $50 / 50$ extruded at $130^{\circ} \mathrm{C}$, the lowest amounts of proteins were extracted, i.e. with nearly no polymeric proteins and only small amounts of monomeric proteins being solubilized (Fig 2). Consequently, this suggests a combination of plasticizers, e.g. glycerol and water, was much more favorable for increased polymerization of the proteins. This was observed for the composites extruded at $110^{\circ} \mathrm{C}$ than those produced at $130^{\circ} \mathrm{C}$, where nearly the same amounts of proteins were extracted (WG-MPS-45gly vs. WG-MPS-30gly-20W both at $130^{\circ} \mathrm{C}$ ). For WG-MPS composites containing glycerol and water besides a greater total amount of plasticizer in the blend (50\% vs. $45 \%)$, which played an important role, an interactive plasticizing effect of water and glycerol on the molecular chain mobility of WG proteins was also apparent. This effect on WG proteins seemed to favor the final protein-starch composite system, where the amount of starch did not seem to affect the polymerization/cross-linking behavior of the protein (Fig 2).

A low extractability of the polymeric WG proteins observed in WG-MPS-45gly composites produced at $130^{\circ} \mathrm{C}$ indicates that protein polymerization was more favorable at the higher extrusion temperature (compared to $110^{\circ} \mathrm{C}$ ). Furthermore, a low degree of extractability of 
monomeric proteins in WG-MPS-45gly and WG-MPS-30gly-20W composites at $130^{\circ} \mathrm{C}$ (vs. $110^{\circ} \mathrm{C}$ ) indicates the disruption of intra-molecular bonds and their reorganization into more stable intermolecular disulphide linkages. ${ }^{30}$ These linkages seemed to be strong enough also to "capture" starch in the protein-starch composites. Furthermore, extrusion provided shear mixing and mechanical energy into the protein-starch blend, which also induced protein aggregation in the composite samples, especially those extruded at $130^{\circ} \mathrm{C}$, as observed in previous studies of WG and glycerol blends. ${ }^{10,31,32}$

From the SE-HPLC analysis of the WG-45gly sample extruded at $130^{\circ} \mathrm{C}$ (Fig. 2), a blend of both aggregated polymeric proteins and monomeric proteins similar to the case of the WG-MPS45 gly $70 / 30$ sample extruded at $130^{\circ} \mathrm{C}$, was observed. This agrees with similar protein extrusion studies $^{32}$ indicating that mixing during extrusion may result in severe aggregation inside the extruder barrel. In our study, this aggregation decreased the protein solubility especially at higher temperatures $\left(130^{\circ} \mathrm{C}\right)$ during the actual extrusion step.

\section{Microstructure of protein-starch composites by scanning electron microscopy (SEM)}

The composites with higher protein vs. starch ratio were selected for microstructural study in order to evaluate morphology of the protein matrix and MPS when glycerol and glycerol-water were used. The selected composites were studied by SEM at a 70/30 protein/starch ratio, i.e. the WG-MPS-45gly $\left(130^{\circ} \mathrm{C}\right)$, WG-MPS-30gly-20W $\left(110^{\circ} \mathrm{C}\right)$, and MPS-45gly $\left(130^{\circ} \mathrm{C}\right)$ (Fig. 3). A large variation in the microstructural pattern was observed between the samples studied (Fig. 3). The WG-MPS-45gly (70/30) $\left(130^{\circ} \mathrm{C}\right)$ showed an in-homogenous structure with a relatively high amount of intact starch granules, which were either incorporated in the protein-starch blend (arrow 1) or were separated from the protein matrix (Fig. 3a, arrow 2) together with some voids 
present (Fig. 3a, arrow 3). The WG-MPS-30gly-20W (70/30) sample extruded at $110^{\circ} \mathrm{C}$ showed a microstructure, which was more uniform, i.e. with a protein-starch matrix being rather homogenous with some intact starch granules present (no voids, with a few small cracks in the matrix) (Fig 3b). This result indicates that the added water plasticized (and also hydrated WG protein) while improving starch incorporation into the blend due to plasticization effect of water on proteins and favorable environment for the homogenization of the sample.

The microstructure of the MPS-45gly sample revealed a structural pattern consisting of the highest amount of intact starch granules compared to the protein-starch counterparts in this study (Fig. 3c). It is important to note that some of the starch granules were poorly imbedded in the starch matrix (Fig. 3c, arrows). In summary, the WG-MPS-30gly-20W showed the favorable processing conditions for extruding such protein-modified potato starch composites. Therefore, more focus should be directed to incorporating all the intact starch granules into a more uniform blend of the components. For the extruded starch samples, a larger processing window with extrusion temperatures higher than $130^{\circ} \mathrm{C}$ extrusion temperatures and the use of water as plasticizer could be explored. Our study on MPS samples produced by extrusion is in agreement with similar studies on potato starch films produced by compression molding, film blowing and casting, ${ }^{8}$ where a complete gelatinization of the initial semi-crystalline structure of the starch was observed to be difficult. In order to disrupt all the intact starch granules, various forms of mixing (i.e. pre-mixing) as well as much higher temperatures, e.g. $140^{\circ} \mathrm{C}$ and higher, are necessary in order to improve blend component homogenization. In fact, a pre-mixing step of the components before extrusion in this study was not enough to achieve a homogenous sample as also found by Thunwall et al. ${ }^{9}$ 
Mechanical properties of protein-starch composites: the effect of extrusion temperature and composition of the blend

Mechanical properties of the WG-MPS-45gly, WG-MPS-30gly-20W composites and MPS45gly extrudates are shown in Fig. 4. An increase in extrusion temperature (from $110^{\circ} \mathrm{C}$ to $130^{\circ} \mathrm{C}$ ) resulted in a significant increase in the E-modulus and maximum stress in WG-MPS45gly composites. A significant increase in extensibility of WG-MPS-45gly composites correlates with an increase in the protein content for $30 / 70$ and $50 / 50$ samples at $110^{\circ} \mathrm{C}$, no such correlation was observed at $130^{\circ} \mathrm{C}$ (Fig. 4). An increase in the protein content (from 30 to $70 \%$ ) in the composites resulted in a significant decrease in E-modulus and maximum stress at $130^{\circ} \mathrm{C}$ (Fig. 4). The MPS-45gly samples extruded at both temperatures studied showed the highest Emodulus and maximum stress, with similar extensibility compared to the WG-MPS-45gly samples (Fig. 4).

In this study, the main purpose was to produce WG-MPS samples using glycerol as the plasticizer; however water was added to several samples in order to improve the processability of the blend during extrusion. The WG-MPS-30gly-20W samples showed the highest tensile properties in terms of modulus, maximum stress and extensibility, when compared to all the WG-MPS-45gly samples produced without water (Fig. 4). Hence water was acting as a plasticizer here (modulus increased in its presence), but primarily led to increased degree of gelatinization of starch granules. In biopolymer systems e.g. proteins, water acts as a plasticizer and contributes in developing the hydrogen bond interactions. These interactions has been

reported to improve the strength and elasticity of WG based films. ${ }^{33}$ In this study we used potato starch with a slightly increased amylose content (27\%), also containing modified amylopectin structure, which as expected, showed that a careful selection of plasticizer (in this case 
combination of glycerol and water) together with optimal extrusion temperature (such as $130^{\circ} \mathrm{C}$ or even higher) is needed in order to obtain a homogenous composite. High amylose potato starch (amylose content $86 \%$ ) is known to have a higher viscosity compared to normal potato starch. ${ }^{9}$ The potato starch used in this study contained only slightly more amylose than ordinary potato starch, but showed 1.7 fold higher viscosity. In addition, the added water seemed to improve gelatinization of the starch. The WG-MPS (30/70), extruded at $130^{\circ} \mathrm{C}$ in the present study, showed a higher maximum stress and lower extensibility in comparison with compression molded WG/potato starch based composites (with $37.5 \%$ plasticizer content). ${ }^{16}$ The WG-MPS showed similar extensibility and slightly higher E-modulus than observed in soy protein/acetylated high amylose corn starch composites with plasticizer content of $30 \% .^{34}$ Slightly lower modulus and maximum stress values in the WG-MPS originate from the fact that a significant portion of starch was still present as granules/intact material. This in turn suggests that an improved adhesion between the WG protein and MPS, as well as increased starch gelatinization, could further improve the tensile properties. In a similar study by Verbeek et al. ${ }^{1}$ the excessive aggregation of WG proteins was found to cause the formation of dense associations in the extruder barrel, resulting in an increase in the viscosity of the blend. ${ }^{1}$ In our study this increase in viscosity, was most likely related to an increase in retention times during extrusion in some cases up to $30 \mathrm{~min}$ which resulted in degradation or excessive aggregation of the proteins (WG-gly45 control samples). However, in this study we were able to show that extensible composites with relatively high maximum stress and extensibility (ca. 90\%) could be obtained with WG protein-potato starch blends containing glycerol and water as plasticizers. The overall behavior indicates that the composites containing glycerol and water have a potential processing window for further improvement of their mechanical properties. 


\section{Protein secondary structure}

FT-IR spectroscopy results in the amide I region (1600-1700 $\mathrm{cm}^{-1}$ ) of WG-MPS-45gly and WGMPS-30gly-20W samples, extruded at 110 and $130^{\circ} \mathrm{C}$, are shown in Fig. 5. It is possible to assess the relative amount of $\alpha$-helices/random coils and $\beta$-sheets by comparing the relative size

of the IR spectrum in the $1645-1660 \mathrm{~cm}^{-1}$ region to that of the $1620-1635 \mathrm{~cm}^{-1}$ region. ${ }^{13}$ To begin with, the relative sizes are not large; the curves are relatively flat in the $1620-1660 \mathrm{~cm}^{-1}$ region. All extruded samples were, however, as expected, more aggregated than the pristine WG powder, the latter having the highest intensities in the $1645-1660 \mathrm{~cm}^{-1}$ region (Fig. 5). This indicated that intensive shear mixing at elevated temperature (extrusion) contributed in transforming the WG protein from a pristine powder with a less organized structure to a more organized aggregated structure.

A slightly more aggregated structure was observed in the WG-MPS-45gly (30/70, 70/30) samples extruded at the higher temperature, whereas no differences could be observed for those with a 50/50 WG/MPS ratio.

The WG-MPS-30gly-20W (50/50) composites contained a higher amount of $\beta$-sheets when extruded at $110^{\circ} \mathrm{C}$ compared to at $130^{\circ} \mathrm{C}$ (Fig. 5). This suggests that the lower extrusion temperature $\left(110^{\circ} \mathrm{C}\right)$, in the presence of water, favors sulfhydryl-disulphide interchange reactions $^{1,31}$ in the WG protein (more monomeric proteins, Fig 2) and formation of sizeable amounts of hydrogen bonding ( $\beta$-sheets).

\section{Wide angle $X$-ray scattering}

The WAXS scattering data of WG-MPS and MPS plasticized extrudates, and MPS powder is shown in Fig. 6. For all the samples studied a large number of peaks indicating the crystalline 
nature of MPS were observed (Fig. 6a; peaks indicated by lines). From diffractograms of the WG-MPS extrudates compared to the MPS powder and crystalline starch structures previously reported, ${ }^{35}$ it can be concluded that the B-type crystalline starch structure is present in the WGMPS samples at both 110 and $130^{\circ} \mathrm{C}$. The main scattering reflections found in the MPS powder are indicated with their correspondent Miller index (Fig. 6a; indicated by their miller indices). ${ }^{35}$ At high protein concentrations in the blend (as 70/30) the starch peaks were smaller (at both $110^{\circ} \mathrm{C}$ and $130^{\circ} \mathrm{C}$ ) (Fig. 6a, b), whereas the impact of the amorphous morphology of $\mathrm{WG}^{36}$ on the WAXS pattern was obvious. In addition, a decrease in starch crystallinity was observed for the WG-MPS blends at $130^{\circ} \mathrm{Ccompared}$ to $110^{\circ} \mathrm{C}$, e.g. starch peaks were less intense and broader (Fig. 6a and 6b).

The addition of water in the WG-MPS-30gly-20W extrudates seemed to reduce the crystallinity of starch in the blend at both 110 and $130^{\circ} \mathrm{C}$ temperatures (Fig. 6c). This was particularly clear for the samples extruded at $130^{\circ} \mathrm{C}$ with the diffraction pattern of small and poorly defined crystalline peaks compared with the pattern of water-free samples (Fig. 6c). In this study, the greater transformation of the starch granules morphology occurred when the glycerol-water vs. glycerol was used, and at the higher extrusion temperature of $130^{\circ} \mathrm{C}$. The addition of water contributed to physicochemical changes in MPS with the partial gelatinization of starch granules, resulting in a loss of crystallinity. ${ }^{37}$

The WAXS results showing a decrease in the crystallinity of MPS, especially due to the water used in the blends, explain the improvement in E-modulus, maximum stress and extensibility of materials. The addition of water causes the swelling of the amorphous regions of the starch and the melting of amylopectin crystals. ${ }^{38}$ Even in the presence of WG proteins, gelatinization of 
starch facilitated an improvement and greater homogenization of the blend during extrusion, which ultimately affected the final material properties.

\section{Small angle $X$-ray scattering}

The SAXS curves of the WG-MPS blends and MPS-45gly samples extruded at $110^{\circ} \mathrm{C}$ and $130^{\circ} \mathrm{C}$, are shown in Fig 7. The MPS-45gly samples showed two peaks, a broad peak $d_{l}$ at low $q$ angle and a more defined peak $d_{3}$ at high $q$ value (Fig. 7a, b; $d_{3}$ indicated by arrow). The broad peak $d_{l}$ indicated a characteristic lamellar structure of starch granules with an average period estimated from the position of the peak maxima e.g. $d_{l}=94.7$ and $98.5 \AA$ at 110 and $130^{\circ} \mathrm{C}$, respectively (Table 3, Supplementary information). According to the WAXS results, the $d_{3}$ peak, is a 100 reflection of the B-type crystalline structure of starch indicated the scattering distance between the two double helixes of amylopectin in a hexagonal unit cell ${ }^{35}$, estimated at $16 \AA$ in this study (Table 3, Supplementary information).

Both the composition of the blend and the processing temperature contributed to changes in the morphology of the WG-MPS composites. The WG-MPS-45gly samples (30/70, 50/50 and $70 / 30$ ) extruded at $110^{\circ} \mathrm{C}$ showed a broad peak, $d_{1}$ and two well defined peaks, $d_{2}$ and $d_{3}$, with distances of 89.4-83.6 $\AA$ for $d_{1}, 55 \AA$ for $\mathrm{d}_{2}$, and 16.2-15.9 $\AA$ for $\mathrm{d}_{3}$ (Fig 7a, b; Table 3 (Supplementary information)). The $d_{1}$ peak exhibited the superimposition of two contributions to the scattering, the lamellar structure of starch and the broad correlation distance between aggregated WG proteins previously observed in WG-glycerol films. ${ }^{13,36}$ The scattering distance $d_{2}$ could potentially be interpreted as the first Bragg reflection of the hexagonal structure observed previously in WG based materials. ${ }^{39}$ In this study, we also performed complementary SAXS temperature experiments to examine the dynamic changes in the morphology (data not 
shown here). The Bragg peak ( $d_{2}$ peak in this study) disappeared at $55-60^{\circ} \mathrm{C}$, which resembled the first peak from the hexagonally arranged structure from WG films ${ }^{39}$ (supplementary info, Fig S1), although in this study the other peaks associated with the hexagonal structure were not present. The $d_{2}$ values remained constant for all the compositions of a blend at $110^{\circ} \mathrm{C}$, while the peak intensity increased along with an increase in WG content of the blend (Fig. 7a; enlarged area in the $I x q^{2}$ vs. $q$ plot). The scattering distance $d_{3}$, indicated the presence of crystalline starch, and this distance was not affected by the change in composition of the blend.

The WG-MPS-45gly samples extruded at $130^{\circ} \mathrm{C}$ showed smaller distances for the $d_{1}$ peak compared to the samples extruded at $110^{\circ} \mathrm{C}$ (Fig $7 \mathrm{~b}$; Table 3, Supplementary information). The $d_{1}$ distance of $73.2 \AA$ for the $70 / 30$ (WG-MPS) composite was the smallest and might be attributed to the higher protein content in the sample, resulting in higher crosslinking of the proteins. Similar to the $d_{l}$ distance for extruded WG-30\% glycerol films at $130^{\circ} \mathrm{C}(74.8 \AA)$ as shown in previous studies. ${ }^{6}$

The WG-MPS-30gly-20W (50/50) extruded at 110 and $130^{\circ} \mathrm{C}$ showed smaller distances for $d_{1}$

(74.6 and $71 \AA$ ) and $d_{2}(53$ and $58.6 \AA$ ), respectively compared to the WG-MPS-45gly 50/50 samples (Fig 7c; Table 3 (Supplementary information)). The addition of water resulted in significant decrease in $d_{l}$ distances probably due to strong plasticization of WG proteins or partial gelatinization of the starch.

\section{Oxygen permeability}

The oxygen permeability (OP) of the selected protein-starch and MPS samples were measured at $23^{\circ} \mathrm{C}$ and $38^{\circ} \mathrm{C}(50 \%$ and $90 \% \mathrm{RH}$, respectively) are shown in Table 4 (Supplementary information). The lowest OP values were observed for the WG-MPS-45gly 30/70 composite, 
measured at $23^{\circ} \mathrm{C}$ and $50 \% \mathrm{RH}$ (Table 4). For the higher measurement temperature $\left(38^{\circ} \mathrm{C}\right)$ only the extrudate with the highest protein content was possible to measure $\left(268 \mathrm{~mm} \mathrm{~mL} / \mathrm{m}^{2} 24 \mathrm{~h}\right.$ atm), which showed a 36 fold increase in comparison to $23^{\circ} \mathrm{C}$ and $50 \% \mathrm{RH}$ (Table 4 , Supplementary information).

The OP of the WG-MPS-45gly 70/30 composite showed promising use of this material for example, as multilayer packaging films, compared to synthetic plastics such as polyethylene terephthalate (PET) (Table 4, Supplementary information), although the mechanical properties would be compromised. In addition, the WG-MPS composite gas permeability can be compared with other WG based composites i.e. WG/nano-clay. ${ }^{6}$ The WG-MPS composite (70/30) showed better barrier properties when a greater amount of protein and $45 \%$ glycerol were used in the blend.

\section{Conclusions}

Modified potato starch (MPS) consisted of longer glucan chains in the debranched amylopectin fraction and had a slight increase in amylose ratio with respect to native starch (27 vs. 20\%). This resulted in a higher gelatinization temperature and viscosity of the MPS compared to native starch. The WG proteins in the WG-MPS extrudates were more polymerized at $130^{\circ} \mathrm{C}$ than at $110^{\circ} \mathrm{C}$. The secondary structure of $\mathrm{WG}$ proteins indicated a larger amount of $\beta$-sheets for the WG-MPS-45gly 70/30 (130 $\left.{ }^{\circ} \mathrm{C}\right)$ and WG-MPS-30gly-20W 50/50 (110 $\left.\mathrm{C}\right)$.

The microstructural properties of the composites were greatly affected by the composition of the blend, extrusion temperature and plasticizer used. The most favorable processing conditions for extruding of WG-MPS composites have been found when $30 \%$ glycerol-20\% water was used. This resulted into the most homogeneous micro-structural pattern (with few intact starch 
granules) between the samples studied by SEM. The nano-structural morphology of all the composites studied indicated the MPS showing the B-type crystalline structure by WAXS and a characteristic lamellar arrangement of around 100 A by SAXS. The WG proteins showed similar structures for the 50/50 and 70/30 WG-MPS blends at both processing temperatures by SAXS, indicating a morphology resembling to hexagonal structure previously found in WG proteins. A larger amount of WG protein in the blend resulted in an increase in extensibility at $110^{\circ} \mathrm{C}$, and a decrease in both the E-modulus and maximum stress at 110 and $130{ }^{\circ} \mathrm{C}$, respectively.

The blend with $30 \%$ glycerol and $20 \%$ water had the most profound plasticization effect on the mechanical properties of the 50/50 WG-MPS materials i.e. the highest E-modulus, maximum stress and extensibility between the composites studied. The oxygen barrier properties under ambient conditions were improved by the highest amount of protein in the sample (i.e. 70/30), which showed excellent barrier values. Since oxygen permeability is comparable with PET synthetic plastics, this material could be of further interest in exploring multilayer film packaging applications.

\section{Supplementary information}

All tables are included in the supporting information. The supplementary data for SAXS provides information about the $d_{2}$ peak observed in WG-MPS extruded samples. The $d_{2}$ peak disappeared between $50-60^{\circ} \mathrm{C}$, which resembled the hexagonally arranged wheat gluten protein structure as was found in previous studies. This material is available free of charge via the Internet at http://pubs.acs.org. 


\section{Acknowledgements}

The Swedish Governmental Research program Trees and Crops for the Future (TC4F), The Swedish Foundation for Strategic Environmental Research MISTRA, Lyckeby Starch AB and Partnerskap Alnarp are acknowledged for financial support. Acknowledgments are to Maria Luisa-Prieto Linde and Ann-Sofie Fält for their assistance in the lab, Kerstin Brismar, Salla Martilla and Gulaim Seisenbaeva for SEM analysis and William Roy Newson for scientific discussion.

\section{References}

1. Verbeek, C. J. R.; van den Berg, L. E., Macromol. Mater. Eng. 2010, 295, 10-21.

2. Wretfors, C.; Cho, S. W.; Hedenqvist, M. S.; Marttila, S.; Nimmermark, S.; Johansson, E., J. Polym. Environ. 2009, 17, 259-266.

3. Wretfors, C.; Cho, S. W.; Kuktaite, R.; Hedenqvist, M. S.; Marttila, S.; Nimmermark, S.; Johansson, E., J. Mater. Sci. 2010, 45, 4196-4205.

4. Muneer, F.; Johansson, E.; Hedenqvist, M. S.; Gällstedt, M.; Newson, W. R., BioResources 2014, 9, 5246-5261.

5. Blomfeldt, T. O.; Kuktaite, R.; Plivelic, T. S.; Rasheed, F.; Johansson, E.; Hedenqvist, M. S., RSC Adv. 2012, 2, 6617-6627.

6. Kuktaite, R.; Türe, H.; Hedenqvist, M. S.; Gällstedt, M.; Plivelic, T. S., ACS Sustainable Chem. Eng. 2014, 2, 1439-1445.

7. Janssen, L.; Moscicki, L., Thermoplastic starch. John Wiley \& Sons: 2009.

8. Altskär, A.; Andersson, R.; Boldizar, A.; Koch, K.; Stading, M.; Rigdahl, M.; Thunwall, M., Carbohydr. Polym. 2008, 71, 591-597. 
9. Thunwall, M.; Boldizar, A.; Rigdahl, M., Carbohydr. Polym. 2006, 65, 441-446.

10. Ullsten, N. H.; Cho, S.-W.; Spencer, G.; Gällstedt, M.; Johansson, E.; Hedenqvist, M. S., Biomacromolecules 2009, 10, 479-488.

11. Forssell, P.; Lahtinen, R.; Lahelin, M.; Myllärinen, P., Carbohydr. Polym. 2002, 47, 125-129.

12. Pommet, M.; Redl, A.; Guilbert, S.; Morel, M.-H., J. Cereal Sci. 2005, 42, 81-91.

13. Rasheed, F.; Newson, W. R.; Plivelic, T. S.; Kuktaite, R.; Hedenqvist, M. S.; Gallstedt, M.;

Johansson, E., RSC Adv. 2014, 4, 2051-2060.

14. Van Hung, P.; Maeda, T.; Morita, N., Trends Food Sci. Technol. 2006, 17, 448-456.

15. Van Soest, J. J. G.; Borger, D. B., J. Appl. Polym. Sci. 1997, 64, 631-644.

16. Gonzalez-Gutierrez, J.; Partal, P.; Garcia-Morales, M.; Gallegos, C., Bioresour. Technol. 2010, 101, 2007-2013.

17. Oliver, L.; Meinders, M. B. J., J. Cereal Sci. 2011, 54, 409-416.

18. Andersson, M.; Melander, M.; Pojmark, P.; Larsson, H.; Bulow, L.; Hofvander, P., J. Biotechnol. 2006, 123, 137-148.

19. Karimi, M.; Inze, D.; Depicker, A., Trends Plant Sci. 2002, 7, 193-195.

20. Andersson, M.; Trifonova, A.; Andersson, A. B.; Johansson, M.; Bulow, L.; Hofvander, P., Plant Cell Rep. 2003, 22, 261-267.

21. Chrastil, J., Carbohydr. Res. 1987, 159, 154-158.

22. Bertoft, E.; Spoof, L., Carbohydr. Res. 1989, 189, 169-180.

23. Newson, W. R.; Kuktaite, R.; Hedenqvist, M.; Gällstedt, M.; Johansson, E., J. Am. Oil Chem. Soc. 2013, 90, 1229-1237. 
24. Labrador, A.; Cerenius, Y.; Svensson, C.; Theodor, K.; Plivelic, T. In The yellow mini-hutch for SAXS experiments at MAX IV Laboratory, Journal of Physics: Conference Series, 2013; IOP Publishing: 2013; p 072019.

25. Mammen, C. B.; Ursby, T.; Cerenius, Y.; Thunnissen, M.; Als-Nielsen, J.; Larsen, S.; Liljas, A., Acta phys. Pol., A 2002, 101, 595-602.

26. Hammersley, A.; Svensson, S.; Hanfland, M.; Fitch, A.; Hausermann, D., Int. J. High Pressur. Res. 1996, 14, 235-248.

27. Jane, J.; Chen, Y. Y.; Lee, L. F.; McPherson, A. E.; Wong, K. S.; Radosavljevic, M.; Kasemsuwan, T., Cereal Chem. J. 1999, 76, 629-637.

28. Schwall, G. P.; Safford, R.; Westcott, R. J.; Jeffcoat, R.; Tayal, A.; Shi, Y. C.; Gidley, M. J.; Jobling, S. A., Nat. Biotechnol. 2000, 18, 551-554.

29. Hofvander, P.; Andersson, M.; Larsson, C. T.; Larsson, H., Plant Biotechnol. J. 2004, 2, 311320.

30. Johansson, E.; Malik, A. H.; Hussain, A.; Rasheed, F.; Newson, W. R.; Plivelic, T.; Hedenqvist, M. S.; Gällstedt, M.; Kuktaite, R., Cereal Chem. J. 2013, 90, 367-376.

31. Redl, A.; Morel, M. H.; Bonicel, J.; Vergnes, B.; Guilbert, S., Cereal Chem. 1999, 76, 361370.

32. Pommet, M.; Redl, A.; Morel, M.-H.; Domenek, S.; Guilbert, S., Macromol. Symp. 2003, 197, 207-218.

33. Gontard, N.; Guilbert, S.; Cuq, J.-L., J. Food Sci. 1993, 58, 206-211.

34. Huang, H. C.; Chang, T. C.; Jane, J., J. Am. Oil Chem. Soc. 1999, 76, 1101-1108.

35.Nishiyama, Y.; Putaux, J.-l.; Montesanti, N.; Hazemann, J.-L.; Rochas, C., Biomacromolecules 2009, 11, 76-87. 
36. Kuktaite, R.; Plivelic, T. s. S.; Cerenius, Y.; Hedenqvist, M. S.; Gällstedt, M.; Marttila, S.; Ignell, R.; Popineau, Y.; Tranquet, O.; Shewry, P. R.; Johansson, E., Biomacromolecules 2011, $12,1438-1448$.

37. Lai, L. S.; Kokini, J. L., Biotechnology Progress 1991, 7, 251-266.

38. Waigh, T. A.; Gidley, M. J.; Komanshek, B. U.; Donald, A. M., Carbohydr. Res. 2000, 328, 165-176.

39. Kuktaite, R.; Plivelic, T. S.; Türe, H.; Hedenqvist, M. S.; Gällstedt, M.; Marttila, S.;

Johansson, E., RSC Adv. 2012, 2, 11908-11914.

40. Lange, J.; Wyser, Y., Packag. Technol. Sci. 2003, 16, 149-158. 


\section{List of figures}

Figure 1. Gel permeation chromatogram after de-branching of: a) Dinamo starch (solid line) and MPS (pointed line), and SEM micrographs of Dinamo (b) and MPS (c) starches, respectively.

Figure 2. Solubility of polymeric (PP) and monomeric proteins (MP) of WG-MPS-45gly and WG-MPS-30gly-20W composites extruded at $110^{\circ} \mathrm{C}$ and $130^{\circ} \mathrm{C}$ by SE-HPLC; WG-45gly samples extruded at $110^{\circ} \mathrm{C}$ and $130^{\circ} \mathrm{C}$ were used as controls. Arbitrary units (AU) correspond to normalized protein solubility.

Figure 3. SEM micrographs of WG-MPS and MPS samples (a) vertical cross-section in the extrusion direction of WG-MPS-45gly $70 / 30$ extruded at $130^{\circ} \mathrm{C}$; b) WG-MPS-30gly-20W 70/30 extruded at $110^{\circ} \mathrm{C}$, and c) MPS- 45 gly extruded at $130^{\circ} \mathrm{C}$. Bars correspond to $10 \mu \mathrm{m}$.

Figure 4. Mechanical properties of WG-MPS-45gly and WG-MPS-30gly-20W composites extruded at $110^{\circ} \mathrm{C}$ and $130^{\circ} \mathrm{C}$ : a) E-modulus, b) maximum stress and c) extensibility.

Figure 5. FT-IR spectra of all WG-MPS-45gly and WG-MPS-30gly-20W composites extruded at $110^{\circ} \mathrm{C}$ and $130^{\circ} \mathrm{C}$. Spectra range $1645-1660 \mathrm{~cm}^{-1}$ corresponds to $\alpha$-helices and $1620-1635 \mathrm{~cm}^{1}$ to $\beta$-sheets.

Figure 6. WAXS profiles of WG-MPS-45gly and MPS-45gly samples extruded at a) $110^{\circ} \mathrm{C}$, b) $130^{\circ} \mathrm{C}$ and WG-MPS-30gly-20W samples extruded at c) $110^{\circ} \mathrm{C}$ and $130^{\circ} \mathrm{C}$, respectively. Curves are shifted vertically for clarity.

Figure 7. SAXS curves of WG-MPS-45gly, MPS-45gly samples extruded at a) $110^{\circ} \mathrm{C}$ and b) $130^{\circ} \mathrm{C}$, and WG-MPS-30gly-20W extruded at c) $110^{\circ} \mathrm{C}$ and $130^{\circ} \mathrm{C}$. Curves are shifted vertically 
for clarity. I $x q^{2}$ vs $q$ plots in a reduced q-range are added to enhance the behaviour of the $\mathrm{d}_{1}$ and $\mathrm{d}_{2}$ peaks.

Figure 8. Schematic diagram of summarized effects of temperature, composition of the blend on the WG protein polymerization and secondary structure, as well as nano-morphology and mechanical properties of extruded WG-MPS composites. 
Supplementary information for publication

\section{List of Tables}

Table 1. Composition of the blends of WG and MPS with glycerol and glycerol-water.

\begin{tabular}{lccccc}
\hline Abbreviation & $\begin{array}{l}\text { Wheat gluten } \\
\boldsymbol{\%}\end{array}$ & $\begin{array}{l}\text { MPS } \\
\mathbf{\%}\end{array}$ & $\begin{array}{l}\text { Glycerol } \\
\boldsymbol{\%}\end{array}$ & $\begin{array}{l}\text { Water } \\
\boldsymbol{\%}\end{array}$ & $\begin{array}{l}\text { Temperature } \\
{ }^{\circ} \mathbf{C}\end{array}$ \\
\hline WG-MPS-45gly 30/70 & 30 & 70 & 45 & & 110 and 130 \\
WG-MPS-45gly 50/50 & 50 & 50 & 45 & & 110 and 130 \\
WG-MPS-45gly 70/30 & 70 & 30 & 45 & & 110 and 130 \\
WG-MPS-30gly-20W 50/50 & 50 & 50 & 30 & 20 & 110 and 130 \\
WG-MPS-30gly-20W 70/30 & 70 & 30 & 30 & 20 & 110 \\
MPS-45gly & & 100 & 45 & & 110 and 130 \\
WG-45gly & 100 & & 45 & & 110 and 130 \\
\hline
\end{tabular}


Table 2. Amylose content and pasting properties of parental potato variety Dinamo and MPS using a rapid viscoanalyzer. Mean value of triplicates and standard deviation (All values are significantly different when $\mathrm{p}<0.05$.)

\begin{tabular}{lrrrrrrr}
\hline $\begin{array}{l}\text { Starch } \\
\text { type }\end{array}$ & $\begin{array}{r}\text { Amylose } \\
\text { content }^{\text {a }} \\
{[\% \text { \% }}\end{array}$ & $\begin{array}{r}\text { Pasting } \\
\text { temperature } \\
{\left[{ }^{\circ} \mathbf{C}\right]}\end{array}$ & $\begin{array}{r}\text { Peak } \\
\text { viscosity } \\
{[\mathbf{c P}]}\end{array}$ & $\begin{array}{r}\text { Final } \\
\text { viscosity } \\
{[\mathbf{c P}]}\end{array}$ & $\begin{array}{r}\text { Setback } \\
{[\mathbf{c P}]}\end{array}$ & $\begin{array}{r}\text { Breakdown } \\
{[\mathbf{c P}]}\end{array}$ & $\begin{array}{r}\text { peak } \\
\text { time } \\
{[\mathbf{m i n}]}\end{array}$ \\
\hline Dinamo & $18 \pm 1.6$ & $66.8 \pm 0.43$ & $5712 \pm 47$ & $2087 \pm 13$ & $475 \pm 26$ & $4100 \pm 60$ & $2.9 \pm 0.039$ \\
MPS & $27 \pm 3.6$ & $78.6 \pm 1.20$ & $2995 \pm 32$ & $3690 \pm 41$ & $843 \pm 21$ & $148 \pm 18$ & $6.5 \pm 0.039$ \\
\hline
\end{tabular}

${ }^{\mathrm{a}}$ Total amylose content determined by colorimetrical detection 
Table 3. SAXS scattering distances of WG-MPS-45gly, WG-MPS-30gly-20W and MPS-45gly samples.

\begin{tabular}{lllll}
\hline WG/MPS ratio & $\begin{array}{l}\text { Temperature } \\
\left({ }^{\circ} \mathbf{C}\right)\end{array}$ & $\begin{array}{l}\mathbf{d}_{\mathbf{1}} \\
(\mathbf{\AA})\end{array}$ & $\begin{array}{l}\mathbf{d}_{\mathbf{2}} \\
(\mathbf{\AA})\end{array}$ & $\begin{array}{l}\mathbf{d}_{\mathbf{3}} \\
(\mathbf{\AA})\end{array}$ \\
\hline WG-MPS-45gly 30/70 & 110 & 89.4 & 55 & 16.2 \\
\hline WG-MPS-45gly 50/50 & 110 & 85.5 & 55 & 16.1 \\
WG-MPS-45gly 70/30 & 110 & 83.6 & 55 & 15.9 \\
\hline MPS-45gly & 110 & 94.7 & - & 16.2 \\
WG-MPS-45gly 30/70 & 130 & 88.0 & 63.0 & 16.3 \\
WG-MPS-45gly 50/50 & 130 & 81.9 & 63.6 & 16.3 \\
WG-MPS-45gly 70/30 & 130 & 73.2 & 54.4 & 16.2 \\
\hline MPS-45gly & 130 & 98.5 & - & 16.5 \\
WG-MPS-30gly-20W 50/50 & 110 & 74.6 & 53.0 & 16.1 \\
WG-MPS-30gly-20W 50/50 & 130 & 71.0 & 58.9 & 16.2 \\
\hline
\end{tabular}


Table 4. Oxygen permeability values of WG-MPS-45gly and MPS-45gly samples at different conditioning treatments. Standard deviation is in brackets

\begin{tabular}{|c|c|c|}
\hline Samples & $\begin{array}{l}\mathbf{2 3}^{\circ} \mathbf{C}, \mathbf{5 0} \% \mathbf{R H} \\
\left(\mathrm{mm} \mathrm{mL} / \mathrm{m}^{2} 24 \mathrm{~h} \text { atm }\right)\end{array}$ & $\begin{array}{l}\mathbf{3 8}^{\circ} \mathbf{C}, \mathbf{9 0 \%} \mathbf{R H} \\
\left(\mathrm{mm} \mathrm{mL} / \mathrm{m}^{2} 24 \mathrm{~h} \mathrm{~atm}\right)\end{array}$ \\
\hline WG-MPS-45gly 70/30 & $7.39(0.98)$ & $268.35(18.73)$ \\
\hline WG-MPS-45gly 30/70 & $2.68(0.49)$ & OR $>2000$ \\
\hline MPS-45gly & $3.29(1.30)$ & OR $>2000$ \\
\hline $\mathrm{PET}^{\mathrm{a}}$ & $1-5$ & ---- \\
\hline WG-clayb & $6(0.4)$ & ---- \\
\hline
\end{tabular}

i.e. OR is over range values, $\mathrm{RH}$ is relative humidity

${ }^{\mathrm{a}}$ Lange et al., ${ }^{40}$, ${ }^{\mathrm{b}}$ Kuktaite et al., ${ }^{6}$ 


\section{Supplementary data (WAXS)}

In order to improve the understanding regarding the origin of $\mathrm{d}_{2}$, SAXS scans were performed at RT, $35,45,55,60,80$ and $90^{\circ} \mathrm{C}$. The SAXS scans performed at RT, 35 and $45^{\circ} \mathrm{C}$ clearly showed the $\mathrm{d}_{2}$ peak, whereas at $55^{\circ} \mathrm{C}$ the $\mathrm{d}_{2}$ peak was not present (Fig. S1). This was the same result as was previously observed in the WG films with hexagonal structure, (Kuktaite et al., 2012) ${ }^{39}$ i.e. the first Bragg peak disappeared after $55^{\circ} \mathrm{C}$, indicating the disappearance of the hexagonal structure which is present in thermo-treated WG proteins. Furthermore, the MPS samples did not show $\mathrm{d}_{2}$ peaks at 110 and $130^{\circ} \mathrm{C}$, respectively.

Figure S1. SAXS scans performed at different temperatures for WG-MPS-45gly (70/30) composite extruded at $110^{\circ} \mathrm{C}$.

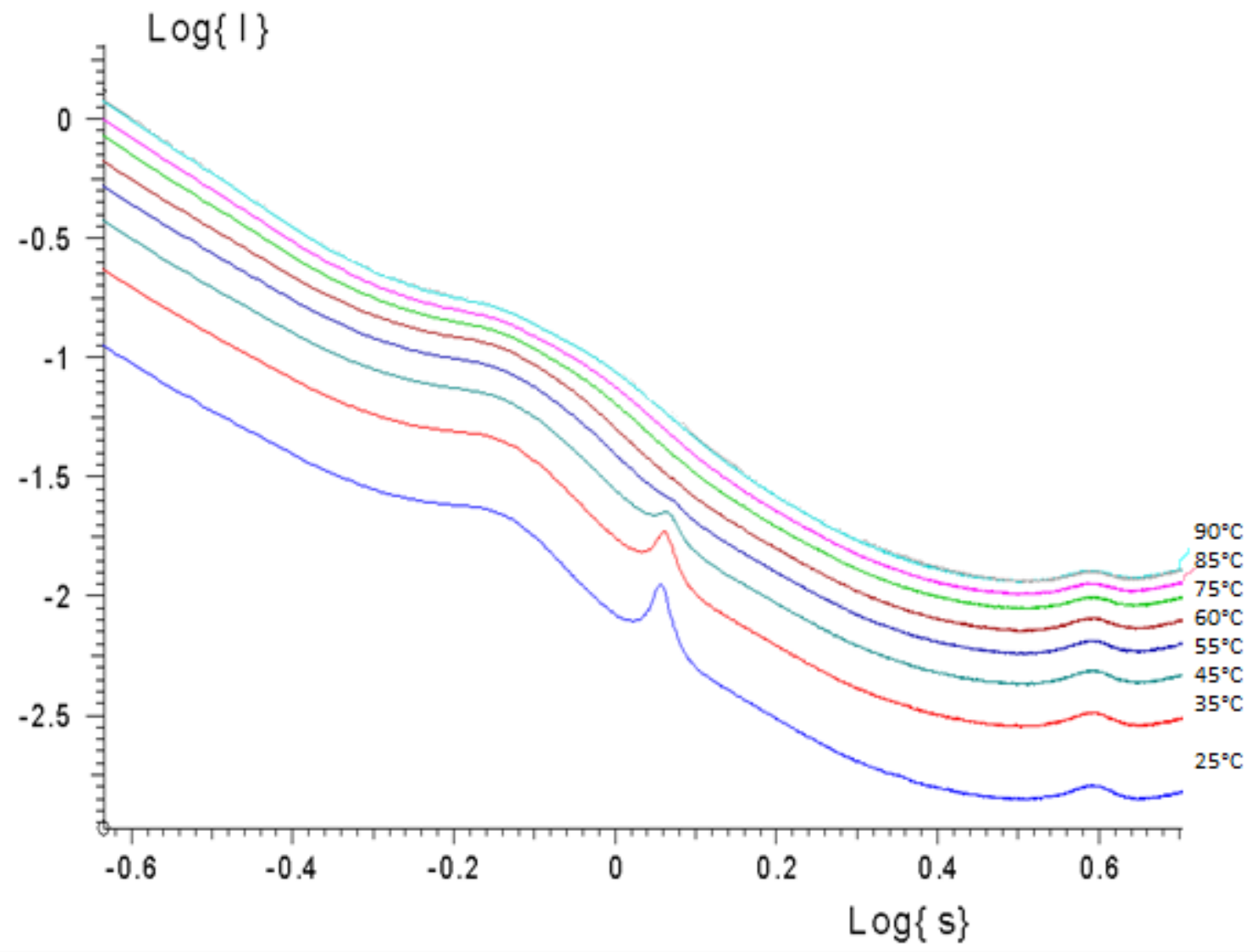




\section{Graphics for manuscript}

Figure 1

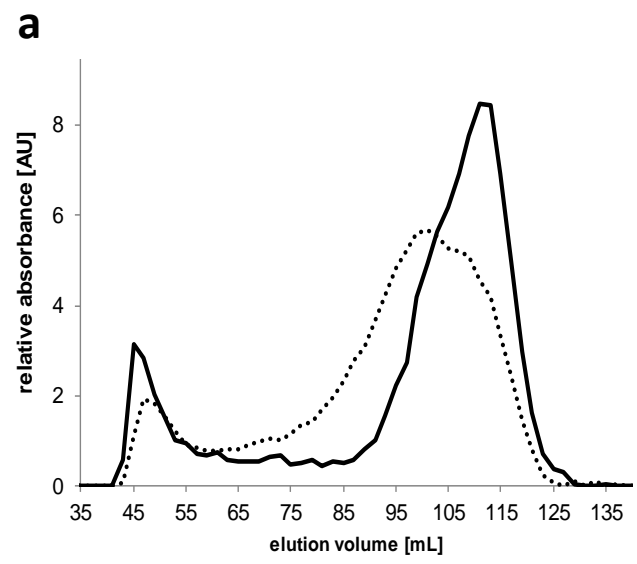

b

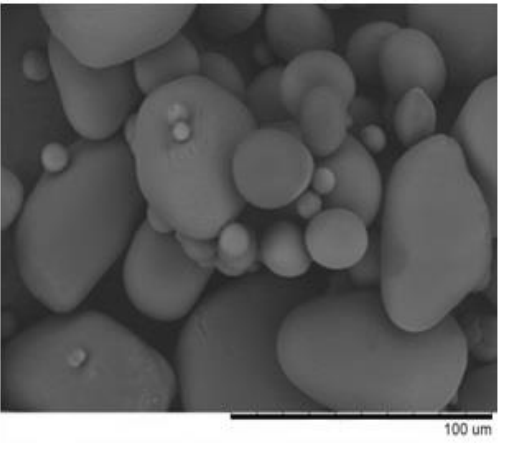

C

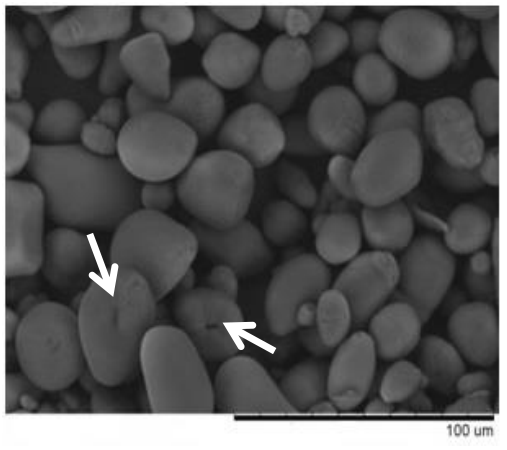


Figure 2

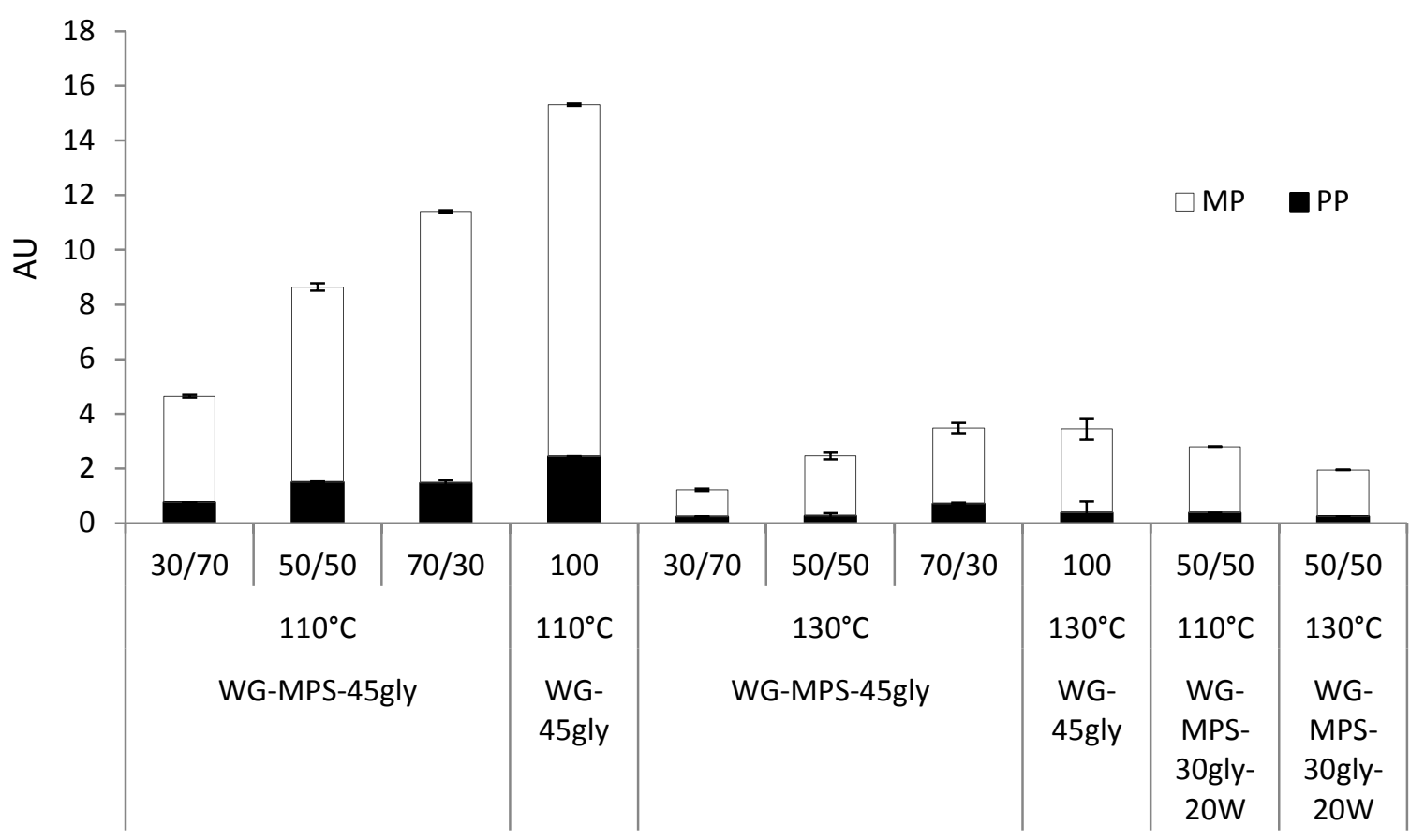


Figure 3

1
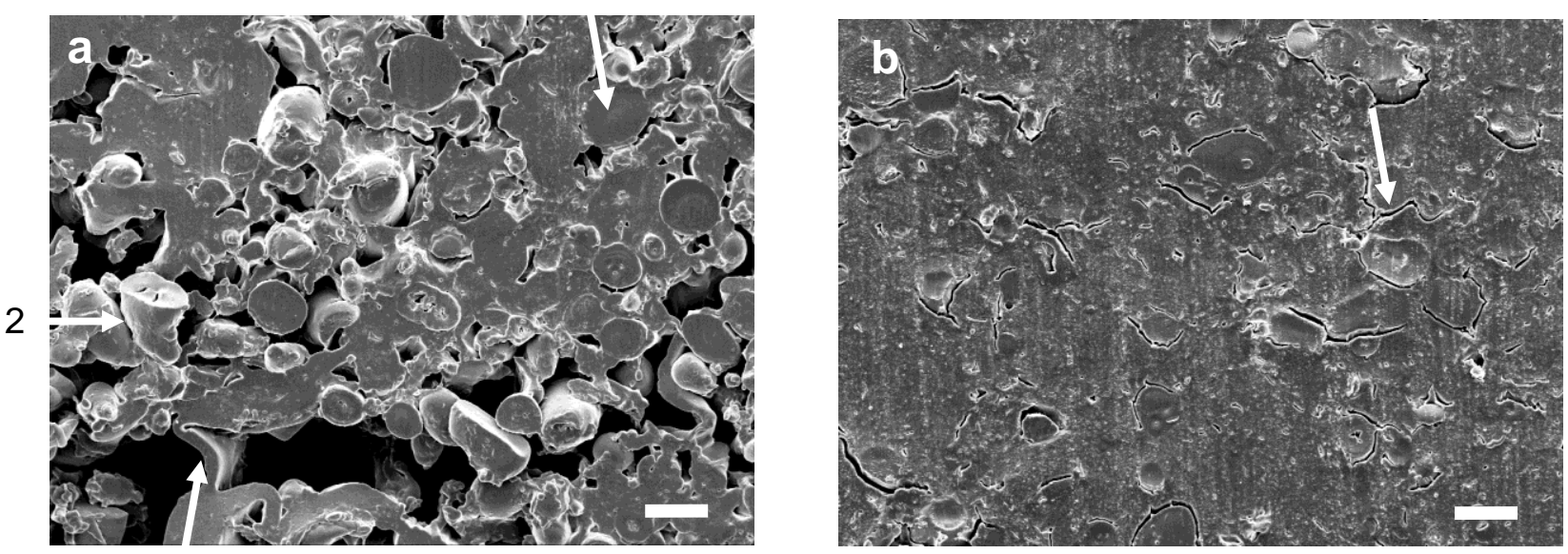

3

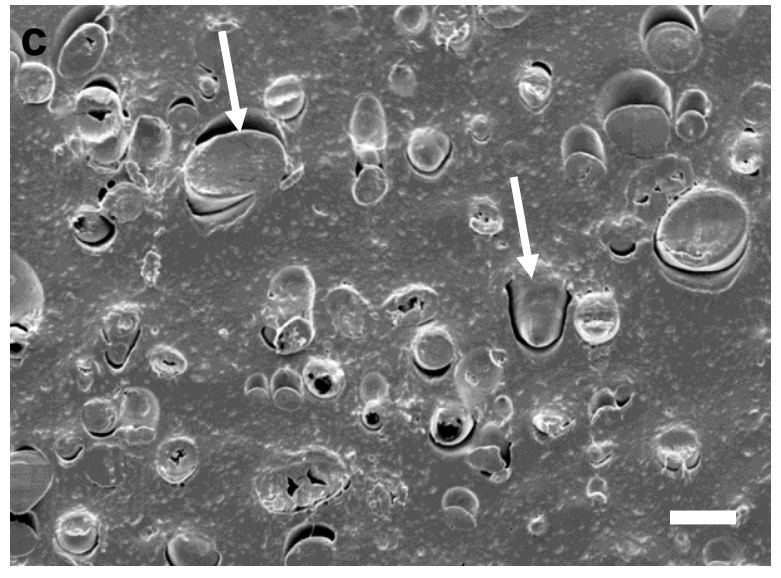


Figure 4
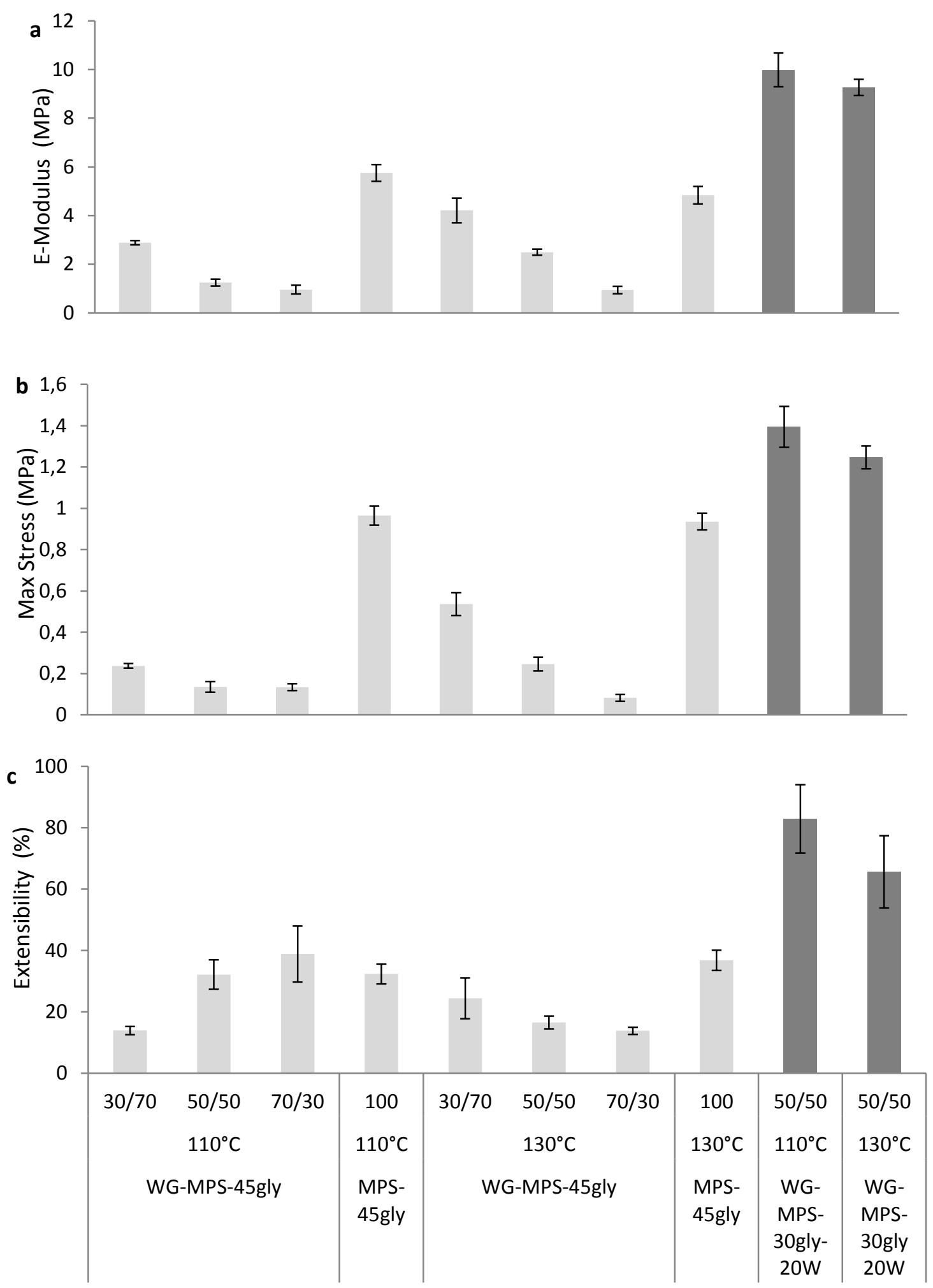


\section{Figure 5}

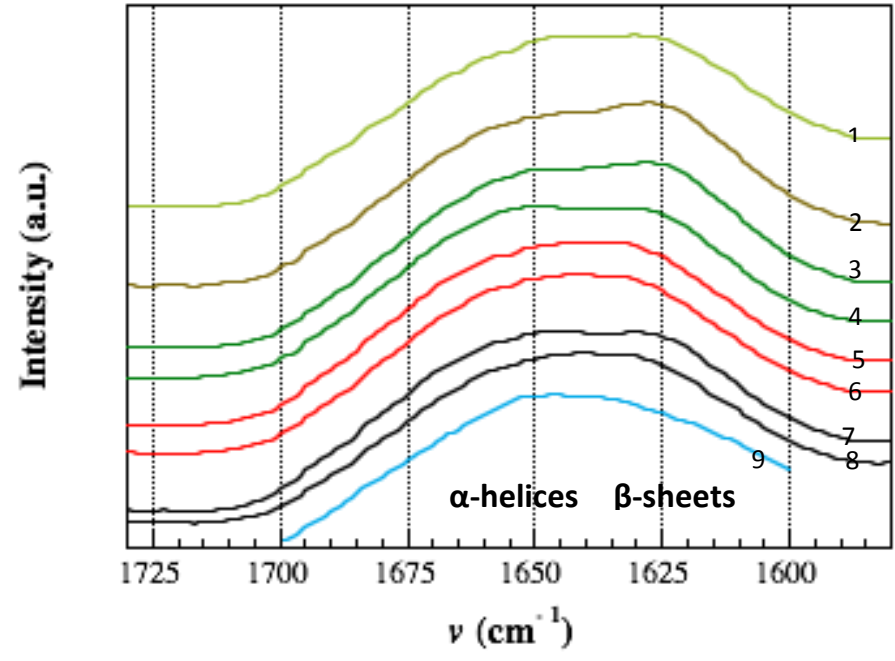

1. WG-MPS-30gly-20W. $(50 / 50) 130^{\circ} \mathrm{C}$

2. WG-MPS-30gly-20W. $(50 / 50) 110^{\circ} \mathrm{C}$

3. WG-MPS-45gly $(70 / 30) 130^{\circ} \mathrm{C}$

4. WG-MPS-45gly $(70 / 30) 110^{\circ} \mathrm{C}$

5. WG-MPS-45gly $(50 / 50) 130^{\circ} \mathrm{C}$

6. WG-MPS-45gly $(50 / 50) 110^{\circ} \mathrm{C}$

7. WG-MPS-45gly (30/70) $130^{\circ} \mathrm{C}$

8. WG-MPS-45gly (30/70) $110^{\circ} \mathrm{C}$ 
Figure 6
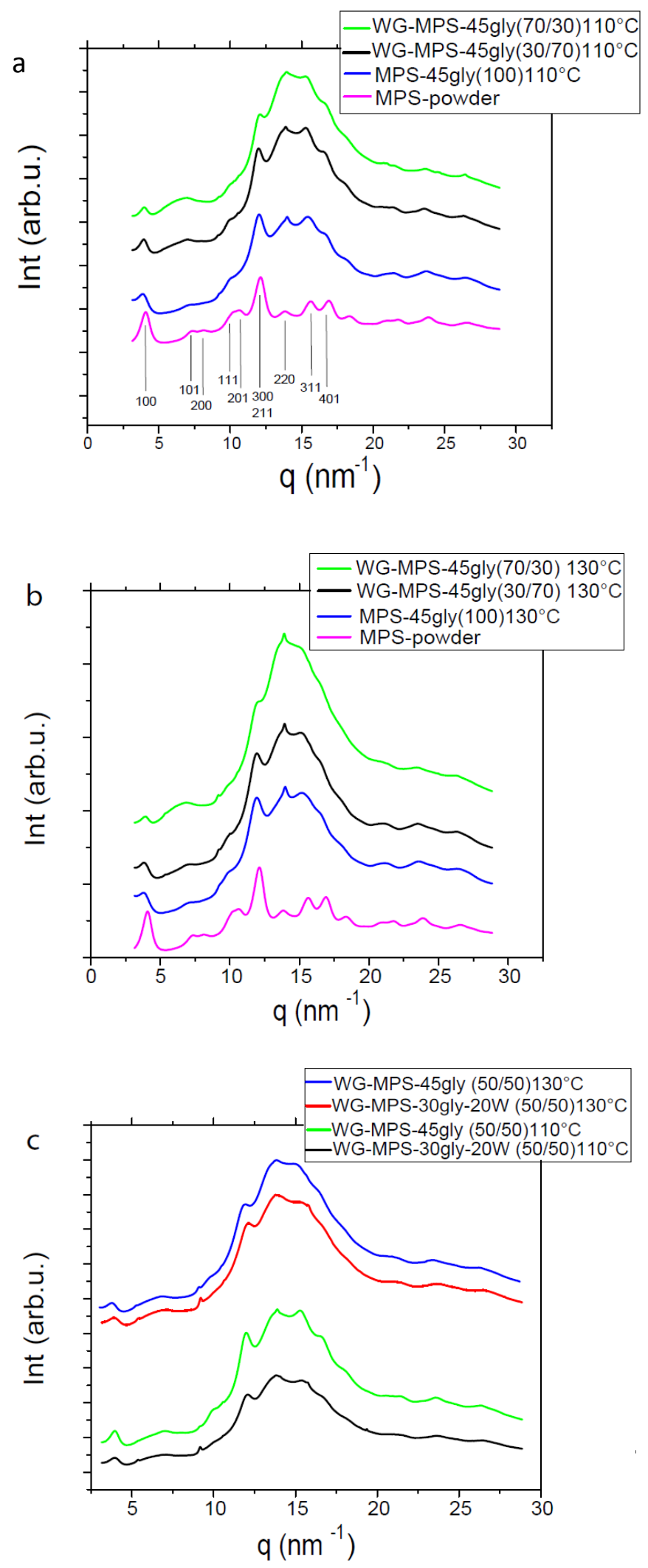


\section{Figure 7}
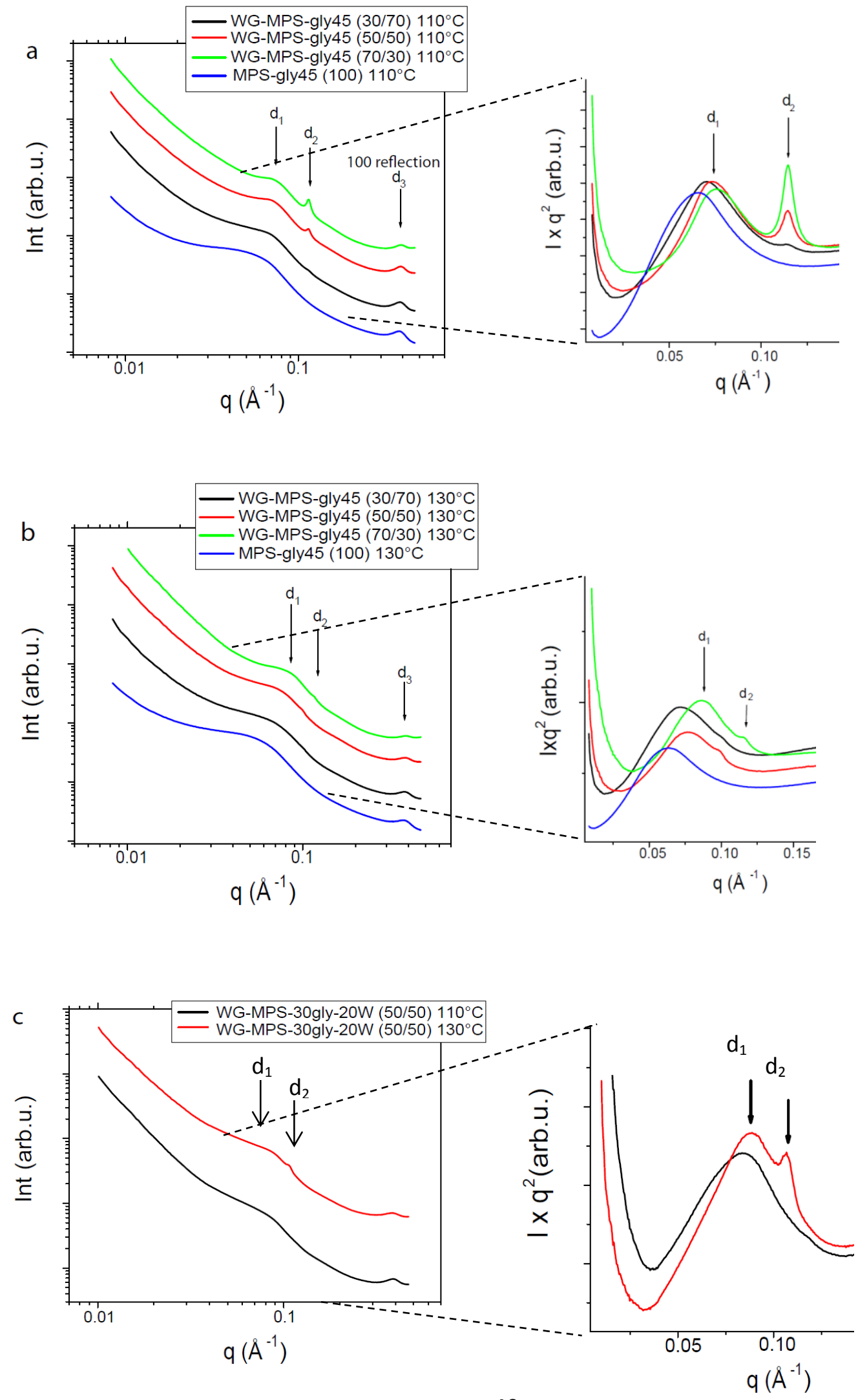


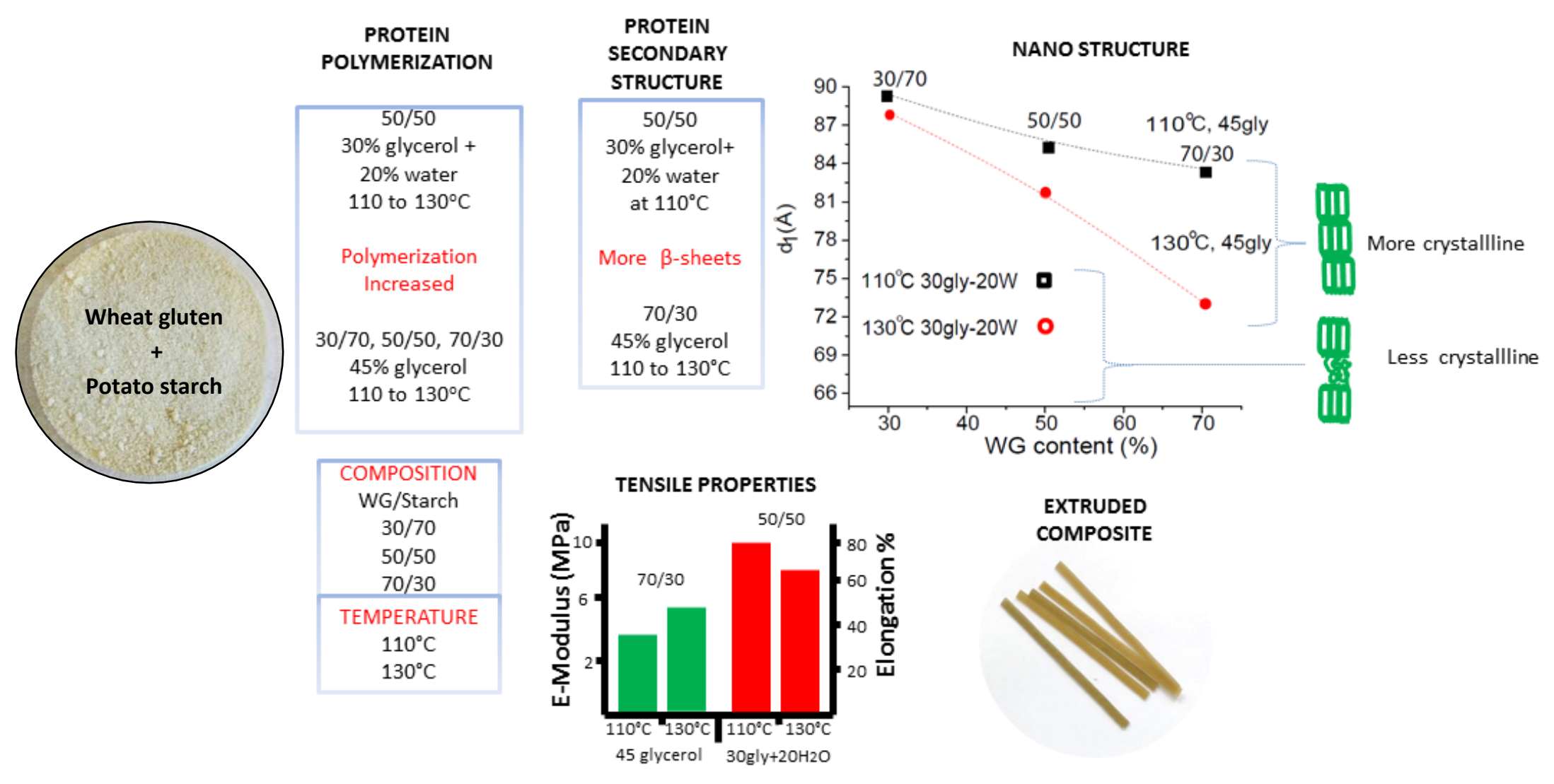


